\title{
Obesity and women health: from womb to tomb
}

\author{
Shivani Garg, Seema Grover, Nishi Garg*
}

Department of Obstetrics and Gynaecology, Guru Gobind Singh Medical College and Hospital, Faridkot, Punjab, India

Received: 27 July 2020

Revised: 12 September 2020

Accepted: 15 September 2020

\section{*Correspondence:}

Dr. Nishi Garg,

E-mail: nishigargdr@yahoo.co.in

Copyright: (c) the author(s), publisher and licensee Medip Academy. This is an open-access article distributed under the terms of the Creative Commons Attribution Non-Commercial License, which permits unrestricted non-commercial use, distribution, and reproduction in any medium, provided the original work is properly cited.

\section{ABSTRACT}

Obesity is a highly prevalent disease reaching epidemic proportions these days in India. Obesity affects all human beings especially women affecting their health drastically. It affects each phase of their life in serious manner. We present here the spectrum of diseases that obesity can cause to a women during her entire life.

Keywords: Obesity, Women health, Polycystic ovary disease, Early puberty, Infertility, Cancer in women

\section{INTRODUCTION}

Even as India battles malnutrition, the country has developed another nutritional problem - obesity. In past 10 years, the number of obese people has doubled in the country (National Family Health Survey-4). India has raced to third place, after United States of America and China in the highest number of obese people worldwide.

Overweight is defined as body mass index (BMI) $\geq 23$, obesity as $\mathrm{BMI} \geq 25$ and abdominal obesity as waist circumference $>90 \mathrm{~cm}$ in men and $>80 \mathrm{~cm}$ in women World Health Organization (WHO) criteria for adult Asians-2004) (Table 1).

The BMI guidelines have been changed for Asians. The earlier accepted cut-off for overweight and obese are used for European and American population.

Obesity is the most bluntly visible disease, yet the most neglected. The morbidity of obesity is immense as it brings with itself a multitude of health risks. Earlier, only adult population was the disease target but in recent years, children and adolescent population have been hit hard by obesity. The reason is creation of an "obesogenic" environment in which the dietary habits are utterly faulty and there is indoor confinement, being hooked to gizmos.
In many cases, the seed of obesity is planted in the womb itself and continues to grow throughout life. We, through this article would like to bring forward the problems obesity brings with itself to women health starting from early childhood to post-menopausal years. We would also like to focus on the remedial measures which must start from the womb and should be continued throughout life to fight the menace of obesity.

Table 1: Classification of weight based on BMI.

\begin{tabular}{|lll|}
\hline Classification & $\begin{array}{l}\text { For adult } \\
\text { Asians-WHO } \\
(\mathbf{2 0 0 4 )}\end{array}$ & $\begin{array}{l}\text { For European/ } \\
\text { American popula- } \\
\text { tion-WHO (1998) }\end{array}$ \\
\hline Underweight & $<18.5$ & $<18.5$ \\
\hline Normal range & $18.5-22.9$ & $18.5-24.9$ \\
\hline Overweight & $>23$ & $>25$ \\
\hline At risk & $23-27.9$ & $25-29.9$ \\
\hline Obese I & $27.5-32.5$ & $30-34 . .9$ \\
\hline Obese II & $32.5-37.5$ & $35-39.9$ \\
\hline
\end{tabular}

OBESITY - IMPACT ON CHILDHOOD AND ADOLESCENCE

The combined prevalence of obese and overweight children has risen significantly from $16.3 \%$ in $2001-2005$ to $19.3 \%$ after 2010 . $^{1}$ 
Obesity during this initial phase of life should be addressed to most strictly, as this phase is the most critical period and a time for developmental plasticity. It is during this time that the body undergoes multiple changes like in body composition, hormonal milieu and psychology. It's during this period that habits form and a personality is shaped. Thus, if excessive weight gain is allowed during this part of life, then it would have a tremendous influence during the latter part of life and many health issues can occur, both during these formative years and adulthood (Table 2). ${ }^{2-6}$

Table 2: Complications of obesity in childhood and adolescence.

\begin{tabular}{|c|c|c|}
\hline S. no. & Complications during childhood & Complications during adolescence \\
\hline 1 & $\begin{array}{l}\text { Puberty disorders - early onset of } \\
\text { puberty }\end{array}$ & $\begin{array}{l}\text { Menstrual irregularities: oligo-hypomenorrhoea, amenorrhoea, } \\
\text { menorrhagia and polymenorrhoea }\end{array}$ \\
\hline 2 & & Polycystic ovarian syndrome \\
\hline 3 & \multicolumn{2}{|c|}{$\begin{array}{l}\text { Increased risk for metabolic disorders like diabetes, hypertension, dyslipidemia and cardiovascular disorders } \\
\text { in adulthood }\end{array}$} \\
\hline 4 & \multicolumn{2}{|c|}{$\begin{array}{l}\text { Psychological health disorders - depression, anxiety disorders, withdrawal from society, increased risk-taking } \\
\text { behaviours, early indulgence in sexual activities, and eating disorders like anorexia or bullemia nervosa }\end{array}$} \\
\hline
\end{tabular}

The above-mentioned complications can be explained by the fact that adiposity is said to be a metabolic gatekeeper for initiation of puberty. Thus, obesity possibly activates gonadotropin-releasing hormone $(\mathrm{GnRH})$ pulse generator prematurely and causes pubertal initiation centrally. Obesity also causes insulin resistance resulting in hyperinsulinemia which increases the bio available estrogens by reducing the sex hormone binding globulins (SHBG). Hyperinsulinemia is also associated with increased production of androgens which get peripherally aromatised to estrogens resulting in further rise of free estrogens. A state of hyper-estrogenimia, hyperinsulinemia and low SHBG leads to oligoanovulation resulting in menstrual irregularities and polycystic ovarian syndrome (PCOS). PCOS needs a special mention. PCOS is a very common disorder and affects $18.5-26 \%$ of adolescent girls. ${ }^{7,8}$ This disorder can manifest in a heterogenous manner such as oligoanovulation leading to irregular periods, acne, alopecia, hirsutism, acanthosis nigricans and increased body fat mass especially an increased abdominal fat deposition. It may or may not be associated with bulky or polycystic ovaries on an ultrasound. PCOS leads to deranged body metabolism and further deposition of body fat, so PCOS and obesity form a vicious cycle. ${ }^{9}$

Thus, comes up the importance of breaking this vicious cycle by actively monitoring and controlling the increase in body weight during adolescent period. It poses an increased risk of infertility, metabolic syndrome, cardiovascular disease, type 2 diabetes, and endometrial carcinoma.

\section{OBESITY - IMPACT ON REPRODUCTIVE YEARS}

In the backdrop of obesity induced disturbed hormonal milieu following complications can occur during reproductive years (Table 3 ). ${ }^{10-12}$

Once, somehow the barrier of conception is crossed in obese women, pregnancy is not free of complications for them.

Table 3: Complications caused by obesity in reproductive years.

\begin{tabular}{|ll|}
\hline Sl. no. & Complications \\
\hline $\mathbf{1}$ & Menstrual irregularities: oligo-hypomenorrhoea, amenorrhoea, menorrhagia, and polymenorrhoea \\
\hline $\mathbf{2}$ & Infertility \\
\hline $\mathbf{3}$ & Pregnancy related complications \\
\hline $\mathbf{4}$ & Decreased efficacy of contraceptives \\
\hline $\mathbf{5}$ & Metabolic syndrome, diabetes, dyslipidemia, and cardiovascular events \\
\hline $\mathbf{6}$ & Psychological health disorders - depression, anxiety, social withdrawal and lack of self-esteem \\
\hline $\mathbf{7}$ & Endometrial, breast, and cervical cancer \\
\hline $\mathbf{8}$ & Obstructive sleep apnoea \\
\hline
\end{tabular}

\section{OBESITY - IMPACT ON PREGNANCY}

Obesity in pregnancy affects each phase of pregnancy and postpartum period and has its effects on the neonate as well. There are strict recommendations for allowable total weight gain of an obese patient $\left(\mathrm{BMI} \geq 30 \mathrm{~kg} / \mathrm{m}^{2}\right)$ during pregnancy and she must gain around $5-10 \mathrm{~kg}$ only to avoid complications during and after pregnancy (Institute of Medicine, 2009).

However, if the total weight gain or rate of weight gain during pregnancy is more than recommended then the risk of complications would increase. The complications that can occur are tabulated in Table $4 .^{13}$ 
Obese women also show decreased efficacy of hormonal contraceptives like oral contraceptive pills, transdermal patches, hormonal injectables, vaginal rings.

\section{OBESITY AND CANCER}

The association between endometrial carcinoma and obesity is strong and is reflected by various studies which show that obesity is associated with at least $40 \%$ of the incidence of endometrial cancer. ${ }^{14,15}$ Not only is the incidence of breast cancer increased but obese women also have greater disease morbidity, including increased risk of breast cancer contralaterally, higher rate of recurrence and higher risk of wound complications after breast surgery. ${ }^{16}$

Cervical cancer is generally seen in lower socioeconomical strata but ironically, obesity is a risk factor for cervical cancer as well. This is because obese women do not visit health facilities for cervical cancer screening. Also, obesity is linked to development of cervical adenocarcinoma likely as compared to squamous cell carcinoma because of exposure to estrogenic hormones. ${ }^{17}$ The studies have not shown much association of ovarian malignancy with obesity. ${ }^{18}$

\section{OBESITY-IMPACT ON POST-MENOPAUSAL YEARS}

Post-menopausal women have a tendency to gain weight owing to genetic, environmental and hormonal factors combined. There is a sudden drop of estrogen with relative increase in androgens and reduced sex hormone binding globulins in post-menopausal period. These hormonal alterations tend to increase the total body fat percentage. Also, there is re-distribution of this body fat with accumulation of the fat over abdomen as compared to deposition over gynoid areas like hips and thighs which occurs during pre-menopausal period. In those women who are genetically predisposed for obesity combined with environmental factors like poor dietary habits and lack of physical activity, excessive fat deposition begins in the post-menopausal period. ${ }^{19}$ The lack of physical activity during this phase is a result of lack of motivation owing to post-menopausal symptoms coupled up with musculoskeletal pains, and osteoarthritis which are age related troubles accelerated by menopause.

Obesity causes the following problems listed in Table 5 to a post-menopausal woman. ${ }^{20}$

Table 4: Complications caused by obesity in pregnant women.

\begin{tabular}{|c|c|}
\hline Phase of pregnancy & Complications \\
\hline \multirow{3}{*}{ Early pregnancy } & Spontaneous abortion \\
\hline & Recurrent miscarriages \\
\hline & $\begin{array}{l}\text { Congenital anomalies - neural tube defects, cardiovascular, orofacial and limb reduction } \\
\text { anomalies }\end{array}$ \\
\hline \multirow{7}{*}{ Mid-late pregnancy } & Gestational diabetes mellitus \\
\hline & Pre-eclampsia \\
\hline & Pre-term deliveries - both indicated and idiopathic \\
\hline & Still birth \\
\hline & Non-alcoholic fatty liver disease \\
\hline & Obstructive sleep apnoea \\
\hline & Fetal macrosomia \\
\hline \multirow{3}{*}{ Intra-partum } & Cesarean delivery \\
\hline & Birth-injuries \\
\hline & Prolonged labour \\
\hline Post-partum & Surgical site infection/burst abdomen and deep venous thrombosis \\
\hline \multirow{3}{*}{$\begin{array}{l}\text { Neonate and } \\
\text { childhood }\end{array}$} & Preterm birth related complications \\
\hline & Metabolic syndrome and childhood obesity \\
\hline & Psychological disorders - autism, developmental delay, and attention hyperactivity disorder \\
\hline
\end{tabular}

Table 5: Complications caused by obesity in post-menopausal women.

\begin{tabular}{|ll|}
\hline S. no. & Complications \\
\hline $\mathbf{1}$ & Metabolic syndrome, diabetes, dyslipidemia and cardiovascular events \\
\hline $\mathbf{2}$ & Non-alcoholic fatty liver disease \\
\hline $\mathbf{3}$ & Endometrial, breast and cervical cancer \\
\hline $\mathbf{4}$ & Genito-urinary disorders - pelvic organ prolapse and urinary incontinence \\
\hline $\mathbf{5}$ & Musculo-skeletal problems - osteoarthritis and lower backache \\
\hline $\mathbf{6}$ & Sexual dysfunction \\
\hline $\mathbf{7}$ & Psychological health disorders \\
\hline $\mathbf{8}$ & Obstructive sleep apnoea \\
\hline
\end{tabular}




\section{MANAGEMENT}

So, epidemic of obesity must be curbed. Awareness drive to counsel and encourage people of all age groups to adopt a healthy and active lifestyle is the need of hour. Management of obesity begins at home and the initial management strategy is diet management and exercise. Foundation of following a healthy life style must be laid from early childhood years.

\section{Diet management: "A man is what he eats"}

Set specific, measurable, agreed upon, realistic and timely (SMART) weight loss targets. Initiate with a target of losing 1-2 lb/week (The Obesity Society). Target for reduction in total calorie consumption by $500-750 \mathrm{kcal} /$ day to start with. Avoid consumption of fried food, sweetened beverages. Control the portion of food to be consumed during each meal. Meals should not be skipped and having small frequent meals should be the funda. Have plenty of water intake. The diet should be high in fiber content, whole grains, fruits, vegetables and low in sodium content. Restrict sodium consumption to $<2300 \mathrm{mg}$ /day. Avoid having meals in front of television, computer, while playing video games or while walking as one tends to eat mindlessly.

\section{Physical activity management: "No time for exercise now, find time for illness later!”}

Combine exercise with diet management as neither of them alone would suffice to achieve weigh loss targets. Increase physical activity in daily life by taking stairs, doing household work, taking any opportunity to walk around. Take up any outdoor sport one likes. Target doing 150 minutes of moderate intensity or 75 minutes of vigorous intensity exercise per week. Join health groups or have a fitness partner or invest in a pedometer to count your steps and stay motivated. Following a moderate level sustained exercise schedule over the week is more important than vigorous exercise once a week.

\section{Cognitive/behavioural therapy: "It's easier said than done"}

Normally, the obese people are obese because they are handicapped by their habits and habits are hard to be changed. Thus, advising the obese people about diet and exercise may prove just to be futile if it's not coupled up with reinforcement with behavioral changes. There should be regular encouragement for weight loss. Self-monitoring techniques like journaling, measuring calories, counting the steps, maintaining a weight loss diary must be started. The obese individuals should be in regular contact with a clinician or registered dietitian who can constantly motivate and keep a check.

Role of pharmacotherapy and bariatric surgery is limited in a few selected cases.

\section{CONCLUSION}

It's very important to understand the implications obesity has on women health so that the magnitude of the problem is understood and suitable remedial measures are undertaken. After all, only a healthy woman has a healthy home.

Funding: No funding sources

Conflict of interest: None declared

Ethical approval: Not required

\section{REFERENCES}

1. Ranjani H, Mehreen TS, Pradeepa R, Anjana RM, Garg R, Anand K, Mohan V. Epidemiology of childhood overweight \& obesity in India: A systematic review. Indian J Med Res. 2016;143:16074.

2. Burt Solorzano CM, McCartney CR. Obesity and the pubertal transition in girls and boys. Reproduction. 2010;140(3):399-410.

3. Nestler JE, Powers LP, Matt DW, Steingold KA, Plymate SR, Rittmaster RS, et al. A direct effect of hyperinsulinemia on serum sex hormone-binding globulin levels in obese women with the polycystic ovary syndrome. J Clin Endocrinol Metab. 1991;72:83-9.

4. Legro RS, Arslanian SA, Ehrmann DA, Hoeger KM, Murad MH, Pasquali R, et al. Diagnosis and treatment of polycystic ovary syndrome: an Endocrine Society clinical practice guideline. Endocrine Society. J Clin Endocrinol Metab. 2013;98:4565-92.

5. Skinner AC, Perrin EM, Moss LA, Skelton JA. Cardio-metabolic risks and severity of obesity in children and young adults. $\mathrm{N}$ Engl $\mathrm{J}$ Med. 2015;373:1307-17.

6. Devlin MJ. Binge-eating disorder comes of age. Ann Intern Med. 2016;165:445-6.

7. Hickey M, Doherty DA, Atkinson H, Sloboda DM, Franks S, Norman RJ, et al. Clinical, ultrasound and biochemical features of polycystic ovary syndrome in adolescents: implications for diagnosis. Hum Reprod. 2011;26:1469-77.

8. Muolokwu E, Sanchez J, Bercaw JL, SangiHaghpeykar H, Banszek T, Brandt ML, et al. Paratubal cysts, obesity, and hyperandrogenism. J Pediatr Surg. 2011;46:2164-7.

9. Glueck CJ, Morrison JA, Daniels S, Wang P, Stroop D. Sex hormone-binding globulin, oligomenorrhea, polycystic ovary syndrome, and childhood insulin at age 14 years predict metabolic syndrome and class III obesity at age 24 years. J Pediatr. 2011;159:308-13.

10. Segula D. Complications of obesity in adults: a short review of the literature. Malawi Med J. 2014;26(1):20-4.

11. Modesitt SC, van Nagell JR. The impact of obesity on the incidence and treatment of gynecologic cancers: a review. Obstet Gynecol Surv. 2005;60(10):683-92. 
12. Obesity and reproduction: an educational bulletin. Fertil Steril. 2008;90(5):21-9.

13. ACOG Practice Bulletin No 156: Obesity in Pregnancy. Obstet Gynecol. 2015;112-26.

14. Chang S, Lacey JV, Brinton LA, Hartge P, Adams K, Mouw $\mathrm{T}$, et al. Lifetime weight history and endometrial cancer risk by type of menopausal hormone use in the NIH-AARP diet and health study. Cancer Epidemiol Biomarkers Prev. 2007;16:723-30.

15. Calle EE, Rodriguez C, Walker-Thurmond K, Thun MJ. Overweight, obesity and mortality from cancer in a prospectively studied cohort of US adults. N Engl J Med. 2003;348:1625-38.

16. Cohen SS, Palmieri RT, Nyante SJ, Koralek DO, Kim S, Bradshaw P, et al. Obesity and screening for breast, cervical, and colorectal cancer in women: a review. Cancer. 2008;112:1892-904.

17. Maruthur NM, Bolen SD, Brancati FL, Clark JM. The association of obesity and cervical cancer screening: a systematic review and meta-analysis. Obesity. 2009; 17:375-81.

18. Purdie DM, Green AC. Epidemiology of endometrial cancer. Best Pract Res Clin Obstet Gynaecol. 2001;15:341-54.

19. Kozakowski J, Gietka-Czernel M, Leszczyńska D, Majos A. Obesity in menopause - our negligence or an unfortunate inevitability?. Prz Menopauzalny. 2017;16(2):61-5.

20. Atapattu PM. Obesity at Menopause: An Expanding Problem. J Pat Care. 2015;1:103.

Cite this article as: Garg S, Grover S, Garg N.

Obesity and women health: from womb to tomb. Int $\mathbf{J}$ Reprod Contracept Obstet Gynecol 2020;9:4324-8. 